ISSN 1112-9867

Available online at $\quad$ http://www.jfas.info

\title{
REGIONAL ELECTORAL COMMITTEES AS A DIRECT DEMOCRACY INSTITUTION
}

\author{
K. S. Inalkaeva ${ }^{1}$, M. S. Tepsuev ${ }^{2}$ and A. R. Matyeva, ${ }^{3, *}$ \\ ${ }^{1} \mathrm{PhD}$ (Law), assistant professor, Department of Law Disciplines, Chechen State Pedagogical \\ University \\ ${ }^{2} \mathrm{PhD}$ (History), assistant professor, head of Department of Law Disciplines, Chechen State \\ Pedagogical University \\ ${ }^{3}$ Senior lecturer, Department of Law Disciplines, Chechen State Pedagogical University
}

Published online: 08 August 2017

\begin{abstract}
This paper offers an analysis of the statutory framework that defines and provides the procedures used to organize and conduct elections. The issues of legal regulation and performance of regional electoral committees are scrutinized. We outline the brief history of and peculiar issues associated with the establishment and evolution of the Central Electoral Committee of the Chechen Republic. A series of measures aimed at eliminating the problems and obstacles hindering the implementation of elective principles are proposed.
\end{abstract}

Keywords: constitution, parliament, elections, referendum, political party, suffrage, legislation, principle public officer.

Author Correspondence, e-mail: amina-mr@yandex.ru

doi: http://dx.doi.org/10.4314/jfas.v9i2s.849 


\section{INTRODUCTION}

The topicality of the paper is determined by the growth of the political activity in the Russian society connected with the Russia's development as a democratic state, electoral legislation aims to direct this activity into the electoral precincts from the squares and streets.

The purpose of the paper is to analyze the legislation grounds defining the organization and the procedure of the elections. The approaches used are as follows: first of all, the analysis of the modern legislation base of the modern electoral law in the Russian Federation; secondly, examination of educational, academic and publicistic works devoted to the issues of the electoral law; thirdly, study of correlation between the legislation base and the actual situation.

Theoretical provision and practical recommendations in modernization of the acting legislation in Russia and law enforcement practices in the electrical process are articulated and justified at the end of this research. Scientific developments can be used in scientific research works, in teaching process in lecturing the history of national state and law, constitutional law (electoral law and process) and other educational courses.

\section{METHODOLOGICAL FRAMEWORK.}

The new realities of popular rule democratic institutions require the adoption of appropriate legal acts regulating the electoral process. It is obvious that nowhere in the world there is a situation when the whole nation rules the state in term of politics. Some developed democratic states are striving to achieve this ideal.

Since democratic state regime presupposes the nation to be actively and widely involved in ruling the state, then this should definitely be articulated in the constitution of the state. Constitutions of many foreign states declare the power to be given to people. For example, the Article 3 of the 1958 Constitution in France states that "national sovereignty belongs to people". The same is true for the Article 1 of the Constitution in the Republic of Italy and in the main law of the Republic of Germany (Part 2 Article 20), etc [13].

The current electoral legislation in the Russian Federation has gone through successive stages of establishing, development and improvement. The legal acts regulating the conduct of elections in the Russian Federation are in compliance with the international electoral 
standards and are aimed at the further development of democratic institutions.

According to contemporary ideas and views, elections are the cornerstone element of direct democracy embodying an effective instrument of bridging differences and opinions in the society - the ones that destroy mutually beneficial relations between individuals and authorities, generate the problems in economy, politics, and social differentiation which, in their turn, provide ground for grave dissentions among people. Such problems and difficulties create the tensions and conflicts that could potentially lead to major complications in the law enforcement system and law compliance [18].

Therefore, in order to prevent the aforesaid problems and strengthen the democratic society, all parties concerned (primarily the state and the people), with no forfeit of their own rights and independent legal capacity, have to act by way of incessant communication and mutual control, in cases when a feasible and practicable mechanism is in place to involve an individual into the activity of creating, discussing and approving of the decisions pertaining to transformation of the society and government authority in various aspects.

\section{Constitutional provisions for democratic election process in the Russian Federation}

The constitution is the key instrument in the whole structure of legal framework as it is the archetypal, precursory set of provisions for all other laws and regulations of the Russian Federation. The governing law of our country provides, in its Clause 1, the establishment of a republican form of government; Clause 3 consolidates and guarantees the constitutional principles of electoral law, proclaims elections as the means of direct popular vote through which people, as the sole source of power, realize their authoritative privilege [8]. The Federal Law "On the key guarantees of the electoral rights and the right to participate in a referendum for the citizens of the Russian Federation" provides that citizens are eligible to have the right to elect and be elected [20]. In addition to the general electoral regulations, it also includes provisions and norms that are especially important for forming the state government bodies, both at the federal and regional levels.

\section{Regional electoral committees}

Such an institution as electoral committees in the constituent entities of the Russian Federation is established with the aim to organize regional elections and control the work of dependent 
local committees. Although this node in the election system has had its equivalents at the previous stages of the Russian election law development, its current nature is different from that of the provincial electoral committees in the tsarist Russia or of the local electoral committees in the Soviet system. Proceeding from the principle of federalism, the electoral committees in the constituent entities of the Russian Federation have gained certain independence and the status of regional governmental bodies. They are formed by regional authorities and bear responsibility for regional elections.

The federal law, the constitutions (statutes) and laws of the constituent entities of the Russian Federation, and the statutes of municipalities govern the competency, authority and the standard operating procedures of the local electoral committees in the constituent entities of the Russian Federation, of municipal electoral committees, of district and territorial electoral committees in organizing and holding elections to government bodies in the constituent entities of the Russian Federation, to municipal authorities and also referendums in the constituent entities of the Russian Federation and local referendums.

Thus, as per Part 3 of Clause 23 of the Federal Law "On the key guarantees of the electoral rights and the right to participate in a referendum for the citizens of the Russian Federation", the term of office of a regional electoral committee is 5 years. The number of voting members of an electoral committee is governed by the constitution (statute), by the laws of the constituent entity of the Russian federation and can be between 10 and 14 people.

The holders of the right to appoint members of regional electoral committees, in compliance with the Federal Law "On the key guarantees of the electoral rights and the right to participate in a referendum for the citizens of the Russian Federation”, are: the principal public officer of the constituent entity of the Russian Federation (head of the supreme governmental body of the Russian Federation) and an appropriate legislative (representative) body of the constituent entity. Each of them may appoint half of the overall number of the committee members.

The appointing procedure for electoral committees rests on proposals from political parties that nominate lists of candidates eligible for allocation of deputy seats in the State Duma, in a legislative (representative) body of the constituent entity of the Russian Federation. Both the legislative (representative) body in the constituent entity of the Russian Federation and the principal public officer of that entity (head of the supreme governmental body of the Russian 
Federation) must appoint minimum one member of the electoral committee in the constituent entity relying on the previously submitted candidates from the Central Electoral Committee of the Russian Federation. This legally mandated procedure of forming electoral committees is to ensure their independence and impartiality.

The scope of authority of electoral committees in the constituent entities of the Russian Federation is provided for in the Federal Law "On the key guarantees of the electoral rights and the right to participate in a referendum for the citizens of the Russian Federation" and is, hence, standard for all constituent entities. The authority of electoral committees also encompasses monitoring of the observance of the electoral rights of citizens, holding special events to organize elections and referendums, supervising the development and improvement of the Elections State Automated System, etc.

Since 2005, regional electoral committees have been granted authority to audit the financial statements of the regional branches of political parties. The corresponding supervisory responsibilities are borne by the controlling and auditing services under the respective electoral committees. Election law experts point out that in today's Russia, for a successful election campaign to be implemented, a political party must have substantial financial resources whose proper leveraging for electioneering can bring significant advantage. This is the reason why at this stage of pre-election campaigning, what we need is a transparent model of political parties' election activity financing [20].

The regional electoral committees are responsible for organizing the work of the dependent nodes in the system. They appoint members of territorial electoral committees and control, within their jurisdiction, the work of municipal committees. On the way a regional electoral committee organizes the operation of its subordinate nodes depends the controllability of election campaign from drawing up registries of eligible voters (the task which is mainly performed by territorial committees) to vote counting.

The constituent entities of the Russian Federation have, of course, additional opportunities to control certain aspects of the election process. The latest reform of the Russian election and referendum law, along with enhancing the role of the committees and extending their authority to new law-enforcement and political spheres (the electoral committees, in fact, are allowed to protest against certain moves of the government, hold their ground and implement special 
policies to stimulate democratic processes) have a significant impact and imply powers to solve inconsistencies and bridge gaps in the election law. On the other hand, these novelties are incoherent in themselves, as only part of them takes into account the local and historical specifics of different regions. So it would seem reasonable to agree with the opinion of V. V. Goncharov, the Director of Research Institute for Problems of Globalization, Economy and Development of Civil Society, that the main criteria for relegating an issue or problem to the jurisdiction of a constituent entity of the Russian Federation in the area of electoral legal matters, are to be the region's geographical, ethnic and cultural specificity that reflects itself onto different stages of the direct vote of local residents [7]. It is most characteristic of the stage of setting up election districts and ballot sites or financing the election and voting processes. All other legislative norms are to be uniform and consistent. We believe that the election reform has to be continued in what pertains, among other things, to defining the legal capacities of individual regions.

\section{Democratic election process in the Chechen Republic}

The path the Chechen people had to travel to establish democracy and modern forms of government was long and thorny. During this transformation of life, the forms of governance were changed along with the legal frameworks and moral and cultural values. The constantly evolving forms of popular representation in the government have lead to the current electoral system [9].

In January 2000, basing on the Federal Law “On the key guarantees of the electoral rights and the right to participate in a referendum for the citizens of the Russian Federation", the Central Electoral Committee formed the Electoral Committee of the Chechen Republic with 14 voting members.

From 2000 till today, the Electoral Committee of the Chechen Republic has organized and held:

- the elections of the President of the Russian Federation, March 26, 2000;

- the repeat elections of the 3rd State Duma Deputies, August 20, 2002, in the Chechen Republic [1];

- the popular referendum in the Chechen Republic, March 23, 2003, for enacting the Constitution of the Chechen Republic, the Law of the Chechen Republic "On the elections of the President of the Chechen Republic" and the Law of the Chechen Republic "On the 
elections of the Parliament of the Chechen Republic";

- the elections of the President of the Chechen Republic, October 5, 2003;

- the elections of the 4th State Duma Deputies, December 7, 2003;

- the scheduled elections of the President of the Russian Federation, March 26, 2004;

- the pre-term elections of the President of the Chechen Republic, August 29, 2004, as a result of the tragic death of President Akhmat A. Kadyrov;

- the elections to the Parliament of the Chechen Republic, November 27, 2005;

- the referendum of the Chechen Republic about the introduction of changes and amendments to the Constitution of the Chechen Republic, in order to harmonize it with the Federal legislation;

- the regular elections of the 5th State Duma Deputies, December 2, 2007.

Here it ought to be noted that the Parliament Deputies of the Chechen Republic, along with the heads and staff of the houses of the Chechen Parliament, took an active part in preparations for the elections of State Duma Deputies and the Chechen Republic constitution amendments referendum. Massive explanatory work and awareness-raising were set in motion to reach out to the population of the Republic. With this aim in mind, 190 popular meetings were held in the pre-election period it institutions, government agencies, plants and factories, in higher and secondary schools, mosques, offices of NGOs and political parties, etc. Electing A. K. Yakhikhadjiyev - the Chairman of the Committee on Social Policy in the Parliament of the Chechen Republic - Deputy of the State Duma of the Russian Federation testifies to the fact that the legislative assembly of the Republic had by that time gained definite prestige and reputation among the Chechens who continued to pin their hopes for a better future on the institution. All in all, the coverage of the awareness-rising outreach work was as many as 30,000 people. Considerable voting turnout in the elections was secured, among other things, by active explanatory work done by the representatives of the Electoral Committee of the Chechen Republic in preparation for:

- the elections of the President of the Russian Federation, March 26, 2008;

- the elections to the 2nd Parliament of the Chechen Republic, October 12, 2008;

- the elections to the local representative bodies in the Chechen Republic, October 11, 2009;

- the scheduled elections of the 6th State Duma Deputies and regular elections to the local 
representative bodies of the Chechen Republic, December 4, 2011;

- the elections of the President of the Russian Federation, March 4, 2012;

- the elections to the 3rd Parliament of the Chechen Republic, September 8, 2013.

The year 2016 is marked by holding elections at three levels.

Federal level: the elections of the State Duma Deputies. Due to recent amendments to the Federal legislation, the elections are organized along the lines of the mixed electoral system, i.e. 255 Deputies elected according to proportional representation, while the remaining 224 ones by the majoritarian procedure. We have to remember that the current composition of the State Duma was formed by the proportional system rules, i.e. proceeding from party lists.

Regional level: the elections of the President of the Chechen Republic. By force of recent amendments to the Constitution of the Chechen Republic, of May 20, 2012, the President of the Chechen Republic is to be elected by citizens of the Russian Federation residing in the Chechen Republic and eligible for exercising their active electoral rights, by direct popular vote. Due to the voluntary dissolution of the 3rd Chechen Parliament, the pre-term elections of its Deputies are to be held.

Local level: the elections of deputies of local representative bodies in the Chechen Republic, in compliance with the Chechen Republic Law "On the election of deputies of local representative bodies in the Chechen Republic" [10].

In the process of formation and enactment of the electoral law and other statutes and regulations governing the relations between the parties of the electoral process, a definitive role is played by close collaboration between the Electoral Committee and the Parliament of the Chechen Republic.

The fundamental laws enacted by the Parliament of the Chechen Republic confirm " the right to participate in the governance of the Chechen Republic both directly and via representatives; the rights to elect and be elected to public authority bodies and local authorities" [5].

The status, forming procedure, operation and authority of the Electoral Committee of the Chechen Republic are governed by the Law of the Chechen Republic "On the Electoral Committee in the Chechen Republic" (People's Assembly of the Parliament of the Chechen Republic 2006, 2012). Pursuant to this law, the duration of the Electoral Committee of the Chechen Republic is 5 years (Law of the Chechen Republic "On the amendments to the Law of 
the Chechen Republic 'On the Electoral Committee of the Chechen Republic', of December 9, 2010, No. 48-P3), with 13 voting members. Any citizen of the Russian Federation over 18 years of age and entitled to vote can be elected to be a member of the Committee.

A system of territorial electoral committees has been set up and functions on a full-time basis. The status of territorial electoral committees in the Chechen Republic has been mandated by the Law of the Chechen Republic "On the territorial electoral committees of the Chechen Republic" (People's Assembly of the Parliament of the Chechen Republic 2006, 2010). Pursuant to this law, 20 territorial electoral committees have been formed in the Chechen Republic, operating full-time and having the status of legal entities. The term of a territorial committee is five years. The territorial electoral committees may be comprised of between five and fourteen voting members. Quantitatively, the composition of a territorial electoral committee is determined by the Electoral Committee of the Chechen Republic with regard to local peculiarities, to the number of eligible voters listed in the territory under the committee's jurisdiction, and to the finances allocated by the republican budget to ensuring the operation of territorial committees. When organizing and holding Federal, republican, and local referendums, the territorial electoral committees act as referendum committees.

\section{RESULTS.}

The institution of the Electoral Committee of the Chechen Republic is enshrined in the Constitution of the Chechen Republic in its general form. It seems reasonable to add to the Constitution of the Chechen Republic a separate chapter titled "The Electoral System of the Chechen Republic". The importance of this amendment to the Constitution is conditioned by the fact that it is the electoral system which provides people with a democratic tool of forming governmental bodies, which is essentially the criterion of a true democracy. Electoral system is an aggregation of statutes and norms governing the rights of citizens to elect and be elected and enshrining the fundamental principles of organization and conduct of elections; hence the topicality and even urgency of resolving these matters at the constitutional level.

In the 1993 Constitution of the Russian Federation, there are also no provisions strictly defining the electoral system, although in the Constitution of the USSR it was explicitly provided for; also in a number of constitutions (clauses thereof) of some constituent entities of 
the Russian Federation we can find separate chapters treating this matter. For instance, in the Constitution of the Altay Republic, Chapter VIII titled "The Electoral System of the Altay Republic" is devoted to the issues of the electoral system structure and functions thus defining the basic election principles [10]. Similarly, Chapter VIII "Elections" in the Constitution of the Republic of Bashkortostan also provides for the local electoral system principles and functionality [11].

\section{DISCUSSIONS.}

The efforts of the state authorities in the Russian Federation and the state authorities in its subjects, representatives of the political and legal science for the last 10-15 years resulted in the development of a modern, internationally standardized electoral system, including the organizational mechanism to elect the public power bodies at all three levels: Russian Federation, subjects of the Russian Federation and municipal level, and the election institute regulates several thousand of law and subordinate acts. T.M. Byalkina, A.F.Vinogradov, N.I.Vorobev, S.N.Voronov, E.N.Doronin, V.V.Ignatenko, L.E.Gumashvili, A.R.Matyreva, etc. studied the problem of legal regulation of the elections at the level of separate subjects in the Russian Federation. The works of the national scientists uncovered some theoretical aspects in the regional legislation about the elections. However, there is no developed theoretical basis for its understanding, uniform notions, understanding the role and place of the subjects and the Russian Federation in the legislation system. Many questions connected with the regional legislation about the election mainly are only mentioned in many scientific papers and are rather fragmentary in nature. There is no paper devoted to the electoral system in the Chechen Republic. This paper identifies the peculiarities in the development and performance of the Election Commission in the Chechen Republic, the drawbacks in the legislation of both the Russian Federation and the Chechen Republic are identified, and some alternatives for its further improvement are given with due regard of the historic and legal points.

\section{CONCLUSION}

Enshrining the electoral system in the Constitution is the way to eliminate possible limitations of the electoral rights of citizens that could be enacted by statutory instruments, for instance, 
the imposition of excessive eligible age thresholds or local residence qualifications, etc.

\section{RECOMMENDATIONS.}

The present paper is interesting for the students, postgraduates, teachers involved into different kinds of social practices, including the events aimed to increase the electoral activity of the youth, as well as for many other readers interested in the issues of the electoral law and electoral process.

\section{ACKNOWLEDGEMENTS}

This work was supported and funded by the Chechen State Pedagogical University for an initiative scientific research.

\section{REFERENCES}

[1] Central Electoral Committee of the Russian Federation. O Naznachenii Povtornykh Vyborov Deputata Gosudarstvennoy Dumy Federalnogo Sobraniya Rossiyskoy Federatsii Tretego Sozyva po Chechenskomu Odnomandatnomu Okrugu [On Scheduling Re-elections of the 3rd State Duma Deputy for the Chechen Single-seat Constituency]. Resolution of April 13 2000, No. 100.1122-3., 2003.

[2] Chirkin V.Ye. Konstitutsionnoe pravo zarubezhnykh stran [Constitutional Law of Foreign States], Moskva: Yurist, 2008.

[3] Chursina T.I., Orlov A.G., Rakitskaya I.A., Polovchenko K.A. Sovremennye izbiratelnye sistemy [Modern Electoral Systems]. Moscow: RTsOIT, In-oktavo, 2009.

[4] Constitution of the Altay Republic. Enacted by the Law of the Republic of Altay of June 7, 1997, No. 21-4.

[5] Constitution of the Chechen Republic. Enacted by the March 23, 2003 referendum, last revised and amended September 30, 2014.

[6] Constitution of the Republic of Bashkortostan. Enacted by the Law of the Republic of Bashkortostan of December 24, 1993, No. BC-22/16.

[7] Goncharov V.V. Vybornost i Uchastie Grazhdan v Upravlenii Gosudarstvom kak Printsipy Formirovaniya i Funktsionirovaniya Gosudarstvennogo Apparata v Rossii 
[Electivity and Popular Participation in the Governance of the Country as the two Principles of Forming and Functioning the Government Mechanism in Russia]. Juridical World, 2010, 6, 12-17.

[8] Inalkaeva K.S. Privlechenie molodezhi $\mathrm{k}$ uchastiyu $\mathrm{v}$ izbiratelnom protsesse Rossiyskoy Federatsii [Attracting the Youth to Participate in Electoral Process in the Russian Federation]. Vestnik Chechenskogo gosudarstvennogo universiteta: nauchno-analiticheskiy zhurnal, 2016, 3 (23), 114-119

[9] Inalkaeva KS. Vybory kak Vazhneishiy Institut Organizatsii i Funktsionirovaniya Publichnoy Vlasti [Elections as the Key Institution for the Formation and Functioning of Public Authority.] Vestnik Chechenskogo Gosudarstvennogo Universiteta, 2012, 2, 240-244.

[10] Parliament of the Chechen Republic. O Vyborakh Deputatov Predstavitelnykh 11. Organov Munitsipalnykh Obrazovaniy v Chechenskoy Respublike [On the Elections of the Municipal Representative Bodies in the Chechen Republic]. Law of the Chechen Republic of December 29, 2014, No. 59-P3.

[11] People's Assembly of the Parliament of the Chechen Republic. Ob Izbiratelnoy Komissii Chechenskoy Respubliki [On the Electoral Committee of the Chechen Republic]. The Law of the Chechen Republic of July 10, 2006, No. 15-P3 (revised December 29, 2012).

[12] People's Assembly of the Parliament of the Chechen Republic. O Territorialnykh Izbiratelnykh Komissiyakh Chechenskoy Respubliki [On the Territorial Electoral Committees of the Chechen Republic]. The Law of the Chechen Republic of July 10, 2006, No. 17-P3 (revised November 09, 2010).

[13] Popadyuk O.A. Stanovlenie i razvitie konstitutsionno-pravovoy sistemy ryada zarubezhnykh gosudarstv [Formation and Development of Constitutional Legal Systems in a Number of Foreign States]: Dis.kand. of law science. Moscow: Moscow State Institute of International Relations (University) of the MFA of Russia, 2011.

[14] Russian State Duma. Ob Osnovnykh Garantiyakh Izbiratelnykh Prav i Prava na Uchastie v Referendume Grazhdan Rossiyskoy Federatsii [On the Key Guarantees of the Electoral Rights and the Right to Participate in a Referendum for the Citizens of 
the Russian Federation]. Federal Law of June 12, 2002, No. 67-Ф3 (last revised and amended March 09, 2016).

[15] Rybakov A.V. Izbiratelnoe pravo i izbiratelnye sistemy [Electoral Law and Electoral Systems]. Moscow: Russian State University for the Humanities, 2013.

[16] Strashun B.A. Konstitutsionnoe (gosudarstvennoe) pravo zarubezhnykh stran [Constitional (State) Law in Foreign States], 3d edition, Moscow: BEK, 2000.

[17] Taagepera R., Shugart M.S. Opisanie izbiratelnykh sistem [Description of Electoral Systems], Moscow: Polis, lektsiya №3, [Electronic Recourse]. http://www.pavroz.ru/files.

[18] Voloshin SE. Izbiratelnaya Sistema Rossii: Aktualnye Voprosy i Zadachi [Russian Electoral System: Urgent Issues And Important Tasks]. Saint Petersburg: Norma, 2005.

[19] Wollerstain M. Izbiratelnye sistemy, partii i politicheskaya stabilnost [Electoral Systems, Parties and Political Stability], Moscow: Polis, 1997.

[20] Zhestovskaya F.A. Konstitutsionno-pravovaya Otvetstvennost v Sfere Vyborov i Referendumov [Constitutional and Legal Responsibilities in the Sphere of Elections and Referendums]. The Review of Economy, the Law and Sociology, 2011, 1, 128-132.

How to cite this article:

Inalkaeva K S, Tepsuev M S, Matyeva A R. Regional electoral committees as a direct democracy institution. J. Fundam. Appl. Sci., 2017, 9(2S), 1375-1387. 